Endocrinopathies affect HRQOL in cancer survivors

\title{
Endocrine and metabolic disorders in survivors of childhood cancers and health-related quality of life and physical activity
}

\begin{abstract}
Kamnesh R. Pradhan ${ }^{1}$, Yan Chen ${ }^{2}$, Sogol Moustoufi-Moab ${ }^{3}$, Kevin Krull ${ }^{4}$, Kevin C. Oeffinger ${ }^{5}$, Charles Sklar ${ }^{6}$, Gregory T. Armstrong ${ }^{4}$, Kirsten K. Ness ${ }^{4}$, Leslie Robison ${ }^{4}$, Yutaka Yasui ${ }^{2,4}$, Paul C. Nathan $^{7}$

${ }^{l}$ Division of Pediatric Hematology-Oncology, Indiana University School of Medicine, Indianapolis, Indiana; ${ }^{2}$ University of Alberta School of Public Health, Alberta, Canada; ${ }^{3}$ Children's Hospital of Philadelphia, University of Pennsylvania Perelman School of Medicine, Philadelphia, Pennsylvania; ${ }^{4}$ Department of Epidemiology and Cancer Control, St. Jude Children's Research Hospital, Memphis, Tennessee; ${ }^{5}$ Duke University School of Medicine, Durham, North Carolina; ${ }^{6}$ Memorial Sloan Kettering Cancer Center, New York City, New York; ${ }^{7}$ The Hospital for Sick Children, Division of Hematology/Oncology, Toronto, Canada.
\end{abstract}

ORCiD numbers:

0000-0002-1488-5992

Pradhan

Kamnesh

Received 15 March 2019. Accepted 02 July 2019.

\section{Context}

Childhood cancer survivors experience chronic health conditions that impact health related quality of life (HRQOL) and participation in optimal physical activity.

\section{Objective}

The study aimed to determine independent effects of endocrine and metabolic disorders on HRQOL and physical activity.

\section{Design, Setting, and Patients}

Retrospective cohort with longitudinal follow-up of survivors of childhood cancer enrolled in the North American Childhood Cancer Survivor Study.

\section{Main Outcome Measures}

Medical Outcomes Short Form-36 estimated HRQOL while participation in physical activity was dichotomized as meeting or not meeting recommendations from the Center for Disease Control and Prevention. Log binomial regression evaluated the association of each endocrine/metabolic disorder with HRQOL scales and physical activity.

\section{Results}

Of 7,287 survivors, median age 32 years (18-54) at their last follow-up survey, 4,884 (67\%) reported one or more endocrine/metabolic disorders. Survivors with either disorder were significantly more likely to be male, older, received radiation treatment, and experience other chronic health conditions. After controlling for covariates, survivors with any endocrine/metabolic disorder were more likely to report poor physical function risk ratio ([RR] 1.25; $95 \%$ confidence interval [CI] 1.05-1.48), increased bodily pain (RR 1.27; CI 1.12-1.44), poor general health (RR 1.49; CI 1.32-1.68) and lower vitality (RR 1.21; CI 1.09-1.34) compared to survivors without. The likelihood of meeting recommended physical activity was lower

This is the author's manuscript of the article published in final edited form as:

Pradhan, K. R., Chen, Y., Moustoufi-Moab, S., Krull, K., Oeffinger, K. C., Sklar, C., ... Nathan, P. C. (n.d.). Endocrine and metabolic disorders in survivors of childhood cancers and health-related quality of life and physical activity. The Journal of Clinical Endocrinology \& Metabolism. https://doi.org/10.1210/jc.2019-00627 
among survivors with growth disorders (RR 0.90; CI=0.83-0.97), osteoporosis (RR 0.87; $\mathrm{CI}=0.76-0.99)$, and overweight/obesity (RR 0.92; CI 0.88-0.96).

\section{Conclusion}

Endocrine and metabolic disorders are independently associated with poor HRQOL and suboptimal physical activity among childhood cancer survivors.

Chronic endocrine and metabolic conditions adversely affected health-related quality of life and physical activity among adult survivors of childhood cancers followed in a large North American cohort.

\section{Introduction}

Significant improvements in the treatment of childhood cancer have led to a 5-year overall survival of $>80 \%$, leaving over 420,000 survivors alive in the United States ${ }^{1,2}$ at risk for early onset of cancer or therapy related chronic health conditions. Survivors are also at risk for poor health-related quality of life (HRQOL) ${ }^{3}$, and are less likely than peers to meet recommended guidelines for physical activity ${ }^{4,5}$. Previous research has identified cranial radiation exposure as a risk factor for reduced HRQOL, and less than optimal participation in physical activity ${ }^{5}$. However, not all survivors with this exposure experience these adverse outcomes. Given that exposures among adult survivors of childhood cancer who have lived for years after treatment are remote to both perceived quality of life and health behaviors, examination of the impact of potentially treatable organ-specific chronic health conditions on these outcomes is warranted; however, research in this area is limited ${ }^{6-9}$.

Endocrine and metabolic disorders are among the most common chronic health conditions experienced by survivors, ${ }^{10,11,12-22}$ and often one condition contributes to additional conditions across the endocrine system. For example, growth hormone deficiency is associated with obesity, and sex-hormone deficiency with low bone mineral density. In the Childhood Cancer Survivor Study (CCSS), approximately $40-50 \%$ of survivors reported at least one endocrine disorder, a rate significantly higher compared with siblings ${ }^{22}$. In that study and other work from the CCSS, metabolic conditions such as obesity and overweight were grouped together with other endocrinopathies. Endocrine and metabolic disorders have been associated with lower levels of physical activity and difficulties managing self-care and activities of daily living ${ }^{6,9,23}$. However, the individual contribution of specific endocrinopathies or overweight/obesity on HRQOL and physical activity are unknown. Consequently, the primary aim of this study was to investigate the independent effects of the most common endocrine disorders and overweight/obesity on HRQOL and physical activity and, as a secondary aim, to examine if treatment of these disorders improved these outcomes.

\section{Subjects and Methods}

\section{Participants}

The CCSS is a retrospective cohort study with longitudinal follow-up of adult survivors of childhood cancer. The study design and cohort characteristics have been previously described in detail ${ }^{10,24}$. Briefly, eligible participants were five-year survivors of leukemia, brain tumors, Hodgkin lymphoma, non-Hodgkin lymphoma, Wilms tumor, neuroblastoma, soft tissue sarcoma, or a malignant bone tumor diagnosed prior to age 21 years at one of 26 institutions across the United States and Canada between 1970 and 1986. These analyses included survivors who completed the baseline survey (administered in the mid-1990s) and two follow-up surveys (beginning in 2003 and 2007, respectively), and who were 18 years or older at the time of the 2003 survey. 


\section{Outcome Measures}

The Medical Outcomes Short Form (SF-36) embedded in the 2003 survey was used to measure HRQOL $^{25}$. Participants answered a 36-item questionnaire about their general health, well-being and quality of life over the previous 4-weeks. The SF-36 has two summary scales (physical and mental components) and eight individual subscales (physical function, role physical, bodily pain, general health, vitality, role emotional, social function, mental health). Each scale is presented as a T-score with a general population mean of 50 (standard deviation [SD] $=10$ ). Lower scores indicate worse HRQOL. Poor HRQOL was defined as a T-score of 40 or less ${ }^{3,25}$. Physical activity levels were determined based on self-reported frequency, duration and intensity of moderate and/or vigorous physical activity including participation in an organized activity over the previous four weeks ${ }^{26}$. Survivors who reported participating in recent organized physical activity were considered to have an active lifestyle. Survivors who met the equivalent of 150 minutes of moderate activity per week were classified as meeting the Center for Disease Control and Prevention's (CDC) guidelines ${ }^{4}$.

\section{Independent Variables}

Survivors reported the presence of the following categories of endocrinopathies (grades 1-4 per the common terminology of adverse events CTCAE-version 4.03) ${ }^{10,27}$ : thyroid disorders (hypothyroidism, hyperthyroidism, thyroid cancer, and thyroid nodules), growth disorders (short stature, growth hormone deficiency), gonadal dysfunction, osteoporosis, diabetes mellitus, overweight/obesity, and other endocrine disorders as previously described ${ }^{22}$. They also reported on current height $(\mathrm{cm})$ and body weight $(\mathrm{kg})$ from which body mass index $\left(\mathrm{BMI} ; \mathrm{kg} / \mathrm{m}^{2}\right)$ was calculated. Overweight was defined as BMI of $25 \mathrm{~kg} / \mathrm{m}^{2}$ or greater but $<30 \mathrm{~kg} / \mathrm{m}^{2}$ or a BMI at or above the $85^{\text {th }}$ but less than $95^{\text {th }}$ percentile per age and sex for participants younger than 18 years and obesity was defined as a BMI $>30 \mathrm{~kg} / \mathrm{m}^{2}$ or BMI higher than $95^{\text {th }}$ percentile per age and sex for participants younger than 18 years. Two follow-up questionnaires were used to ascertain the presence of endocrine/metabolic disorders and if survivors were being treated for the condition from the time of study entry until last follow-up. Responses to both surveys were used to define the endocrine condition because the first survey only recorded medications used to treat hormone deficiencies as a proxy for endocrine conditions, whereas the subsequent survey specifically asked survivors to report each endocrinopathy, and the year of onset of that condition, regardless of whether they were receiving treatment or not. Only survivors where the onset of endocrine conditions and replacement therapy for that condition occurred prior to the outcome measures were included in the analyses.

Psychological measures of anxiety, depression and somatization were assessed using the Brief Symptom Inventory-18 (BSI-18), an 18- item scale that was embedded in the 2003 survey with a $\mathrm{T}$ score $\geq 63$ indicating emotional distress within the preceding 7 days ${ }^{28}$. Task efficiency, a neurocognitive construct related to initiating and completing tasks in a rapid manner and associated with lower physical activity, was measured by the CCSS neurocognitive questionnaire (CCSS-NCQ) ${ }^{29}$, a self-reported measure in the 2003 survey. Both were used as adjustment variables when analyzing the physical activity outcomes.

\section{Statistical Analysis}

Demographic and treatment characteristics were compared between survivors with and without self-reported endocrine and metabolic disorders using chi-squared tests for categorical variables and t-test for continuous variables. We repeated this analysis with the exclusion of overweight/obesity as an outcome so that it focused only on endocrinopathies. Log binomial regression was used to evaluate the association of having any endocrine/metabolic disorder, as 
well as the association of each individual endocrine/metabolic disorder with HRQOL and physical activity, followed by similar analyses after excluding overweight/obesity. Specific endocrine disorder therapy (replacement therapy for hypothyroidism, testosterone therapy, and hormone replacement therapy (HRT) for gonadal dysfunction among females), and the total number of endocrine disorders with the probability of a poor score (40 or lower) for each component of HRQOL, and each of the two measures of physical activity were analyzed using log binomial regression. All models were adjusted for sex, race, education, marital status, household income, health insurance, employment status, radiation therapy, amputation, and grade 3-4 (severe or life threatening or disabling) chronic health conditions other than endocrine disorders. The analysis of physical activity outcome was also adjusted for emotional distress and task-efficiency ${ }^{28,30}$.

\section{Results}

\section{Characteristics of study population}

Of the 7,287 survivors who completed the baseline and follow-up surveys and were 18 years or older at the time of the last follow-up survey, 4,884 (67\%) had one or more endocrine or metabolic disorder. Survivors with these disorders were more likely than those without to be male, older at cancer diagnosis and at the time of each survey, and less likely to be employed. They were also more likely to have other grade 3-4 chronic health conditions as well as poor emotional health, and more likely to have received any radiation treatment compared to those without these conditions (Table 1).

\section{Characteristics of endocrine and metabolic disorders}

The most common condition was overweight/obesity, which was present in $50.7 \%$ of survivors (Table 2). Thyroid disorders were the most common endocrinopathy (22.9\%), followed by growth disorders (19\%). Females were more likely to report gonadal dysfunction than males.

Relationship between type and number of endocrine and metabolic disorders and HRQOL Survivors with female gonadal dysfunction relative risk $(\mathrm{RR}=1.26,95 \%$ confidence interval [CI] $=1.08-1.46)$, osteoporosis $(\mathrm{RR}=1.45,95 \% \mathrm{CI}=1.29-1.63)$, diabetes mellitus $(\mathrm{RR}=1.23,95 \%$ $\mathrm{CI}=1.08-1.40)$ or overweight/obesity $(\mathrm{RR}=1.25,95 \% \mathrm{CI}=1.12-1.38)$ had an elevated risk of a poor physical component summary score on the SF-36. Thyroid disorders $(\mathrm{RR}=1.16,95 \%$ $\mathrm{CI}=1.01-1.34)$ and male gonadal dysfunction $(\mathrm{RR}=1.67,95 \% \mathrm{CI}=1.25-2.24)$ were associated with an elevated risk of a poor mental component summary score. The association between additional specific endocrinopathies and poor scores on the sub-scales of the SF-36 are displayed in Table 3.

Survivors with greater than two endocrine/metabolic disorders had an elevated risk of poor physical component summary scores of HRQOL compared to those without a disorder $(\mathrm{RR}=1.7$, 95\% CI=1.3-2.4). In addition, these survivors had a higher risk of limitations in performing physical activities $(\mathrm{RR}=1.8,95 \% \mathrm{CI}=1.2-2.7)$ showing lower scores in physical functioning, increased bodily pain, poor general health, and lower vitality compared to those without any endocrine disorder. Details of the number of endocrine disorders including overweight/obesity and poor scores on the subscales of SF-36 are shown in Table 4.

\section{Relationship between the types and numbers of endocrine and metabolic disorders and physical activity}

As shown in Table 5, participation in recent physical activity consistent with an active lifestyle was lower among those with growth disorders $(\mathrm{RR}=0.95,95 \% \mathrm{CI}=0.91-0.99)$ or diabetes 
mellitus ( $\mathrm{RR}=0.84,95 \% \mathrm{CI}=0.74-0.96)$ compared to those without these endocrine disorders. The likelihood of meeting the CDC guidelines for physical activity was lower among survivors who had a growth disorder $(\mathrm{RR}=0.90,95 \% \mathrm{CI}=0.83-0.97)$, osteoporosis $(\mathrm{RR}=0.87,95 \%$ $\mathrm{CI}=0.76-0.99)$, or overweight/obesity $(\mathrm{RR}=0.92,95 \% \mathrm{CI}=0.88-0.96)$. Table 6 demonstrates that self-reported participation in recent physical activity was less likely among those with more than two endocrine/metabolic disorders compared to those with none $(\mathrm{RR}=0.90,95 \% \mathrm{CI}=0.83-0.97)$ or one $(\mathrm{RR}=0.92,95 \% \mathrm{CI}=0.85-0.99)$. Similarly, survivors with increasing number of endocrine/metabolic disorders were less likely to report meeting the CDC guidelines for physical activity compared to those without these disorders. Those with greater than two endocrine or metabolic disorders were less likely to meet CDC physical activity recommendations compared to two $(\mathrm{RR}=0.84,95 \% \mathrm{CI}=0.73-0.96)$ or fewer $(\mathrm{RR}=0.82,95 \% \mathrm{CI}=0.72-0.94)$.

We did not find any major differences in clinical characteristics, HRQOL sub-scales or physical activity between survivors with and without endocrine disorders after exclusion of overweight/obesity (see supplemental data, available at datadryad.org).

\section{Treatment effect and HRQOL outcomes}

As shown in Table 7, among survivors with hypothyroidism who reported use of thyroid hormone replacement, there was a significant lower risk of general mental health morbidities ( $\mathrm{RR}=0.58,95 \% \mathrm{CI}=0.36-0.93$ ) compared to those not reporting thyroid hormone replacement. Male survivors with gonadal dysfunction who reported use of testosterone had a lower risk for poor physical $(\mathrm{RR}=0.19,95 \% \mathrm{CI}=0.04-0.88)$, role limitations due to emotional problems $(\mathrm{RR}=0.38,95 \% \mathrm{CI}=0.15-0.98)$, social functioning $(\mathrm{RR}=0.22,95 \% \mathrm{CI}=0.05-0.97)$, and poor mental health $(\mathrm{RR}=0.22,95 \% \mathrm{CI}=0.06-0.86)$ compared to those who did not report taking testosterone replacement.

\section{Discussion}

In this study of over 7,000 survivors, we demonstrated an independent association of endocrine and metabolic disorders and reduced HRQOL and physical activity, even after adjusting for factors known to negatively influence these outcomes such as other chronic health conditions, cranial radiation therapy, and neuro-cognitive deficits. Two-thirds of survivors had at least one endocrine or metabolic disorder. These disorders significantly affected both the physical and mental components of HRQOL and were associated with reduced physical activity. In a previous study, an amputation or cranial radiation ${ }^{5}$ significantly affected HRQOL and physical activity. However, we demonstrated that even when adjusting for these treatment variables, endocrine/metabolic disorders have an incremental negative impact on HRQOL and physical activity suggesting that these disorders may be associated with pathophysiological changes that decrease HRQOL.

Compared to survivors without any endocrine or metabolic disorders, a majority of survivors with these disorders reported significant limitations in physical functioning that included difficulties with activities of daily living, pain that limited their physical well-being, and a perception that their general health was poor. They also experienced symptoms of fatigue. The endocrine system integrates a complex set of physical and psychological signals that influence a variety of body systems, allowing an individual to adapt to their environment. While it was previously known that survivors with endocrine disorders are at risk for physical limitations, this analysis elucidated the impact of individual endocrinopathies. For example, survivors with thyroid disorders reported significant limitations in work and activities of daily living due to their physical health, were more likely to feel weak and tired at all times and perceived their general 
health as poor and likely to get worse. While these survivors did not have increased symptoms of anxiety and depression, they did report that emotional problems interfered with their work or daily activities. Similar findings were observed in a Swiss study of childhood cancer survivors in which thyroid disorders were shown to impact all elements of HRQOL ${ }^{6}$. Impairments in HRQOL have been reported in adult, non-cancer populations with thyroid disorders ${ }^{31-34}$. Given the critical role played by thyroid hormones in growth, development, and energy metabolism, and the long latency of developing thyroid disorders after cancer treatment, these finding support the need to remain vigilant for signs or symptoms of thyroid dysfunction in at-risk patients throughout the survivorship trajectory. This is particularly important because survivors who reported taking thyroid hormone replacement showed better overall mental health, an important aspect of HRQOL.

We observed that male survivors with gonadal dysfunction reported more problems at work and performing physical activities of daily living due to poor physical health, more somatic pain, and a general feeling of being fatigued and worn out. Similar to previous reports of males with gonadal dysfunction ${ }^{3536,37}$, these members of our cohort experienced greater functional impairment due to emotional problems, interference in social activities due to these problems, and an increase in symptoms of anxiety and depression. Testosterone deficiency may have limited physical development, such as low muscle mass, and sexual health and function, such as poor libido and infertility. Encouragingly, survivors who reported taking testosterone replacement reported higher physical, social functioning, and mental health on the SF-36 than those not receiving replacement. Female survivors with gonadal dysfunction reported limitations in performing physical activities and increased body pain and feelings of poor physical health, which may be related to poor bone health due to estrogen deficiency ${ }^{38,39}$.

Survivors with diabetes mellitus and overweight/obesity, also reported impairment in physical activity, increased and functionally limiting pain, increased feelings of fatigue and decreased perception of general health and well-being without a significant impact on mental health. Careful and targeted counselling for weight reduction and other lifestyle changes are needed so that improvement in HRQOL can be achieved in these survivors.

The negative impact of endocrine and metabolic disorders on physical domain subscales of the HRQOL was first reported by Ness at al ${ }^{9}$. Our study is the first to show that among survivors with endocrine disorders, those with growth and bone disorders were less likely to report adherence to the CDC physical activity guidelines. These disorders if untreated affect lean muscle mass, muscle and bone strength and may lead to poor exercise tolerance ${ }^{23}$. In addition, survivors with growth disorders also reported an inactive lifestyle. This is significant as it is well known that subjects with growth hormone deficiency are at risk for poor cardiovascular outcomes $^{40}$. Survivors with diabetes mellitus and those who were overweight/obese also reported poor compliance with CDC guidelines. Targeting exercise interventions to this group could produce significant health benefits that may potentially alter the underlying disease trajectories of diabetes and obesity. Our results also showed that it was harder to maintain physical activity with cumulative effects of more than one endocrine/metabolic disorder. These results should prompt exercise interventions for survivors with multiple endocrinopathies.

There are several limitations to this study. First, the diagnosis of endocrine and metabolic disorders was obtained from a self-reported survey. This might underestimate the proportion of survivors with these disorders in our study as previous studies have shown that screening and risk-based assessment frequently detects endocrine disorders that survivors are not aware of ${ }^{41,42}$. The physical activity outcome in this study was a self-reported measure and were not be 
validated against known objective measurements like resting energy expenditures or accelerometers. Due to the study-design, we were not able to determine if survivors were receiving optimum treatment or were compliant with medications prescribed to treat an endocrinopathy and so cannot determine if poorer HRQOL and lower physical activity was associated with having an untreated endocrinopathy, or if even adequately treated endocrinopathies negatively influence these outcomes. However, we observed better outcomes in many aspects of the HRQOL among those survivors reporting taking thyroid and male sex hormones compared to those who were not on these replacement medications. Further investigations are required in the setting of a prospective study design to confirm and validate these findings.

In summary, childhood cancer survivors with endocrine and metabolic disorders are more likely to have functional impairment, decreased physical activity, and an inactive lifestyle. This study provides the first evidence of how each of the more common endocrine and metabolic disorders affects HRQOL and physical activity. Prospective studies designed to evaluate the treatment interventions of these disorders on HRQOL and physical activity are needed to optimize improvement in these outcomes.

National Cancer Institute, CA55727, Gregory T Armstrong; St.Jude Children's Hospital Cancer Center Core Grant, CA21765, Not Applicable

\section{Acknowledgements:}

This work was supported by the National Cancer Institute (CA55727, G.T. Armstrong, Principal Investigator). Support to St. Jude Children's Research Hospital also provided by the Cancer Center Support (CORE) grant (CA21765, C. Roberts, Principal Investigator).

Corresponding Author Contact Information: Kamnesh Pradhan. MD, MS, Address: Riley Hospital for Children, Indiana University School of Medicine, 705, Riley Hospital Drive, Indianapolis, IN 46202, USA., Phone Number: 317-944-8784, Email Address: pkamnesh@iu.edu

Reprint Requests: Kamnesh Pradhan. MD, MS, Address: Riley Hospital for Children, Indiana University School of Medicine, 705, Riley Hospital Drive, Indianapolis, IN 46202, USA.

Disclosure Summary:

KRP is employed by Eli Lilly and Company. The other authors have nothing to disclose.

\section{DATA AVAILABILITY:}

All data generated or analyzed during this study are included in this published article or in the data repositories listed in References.

\section{References}

1. Surveillance, Epidemiology, and End Results Program Cancer Statistics Review (CSR). 1975-2015; https://seer.cancer.gov/csr/1975_2015/browse_csr. Accessed January 3rd, 2019.

2. Robison LL, Hudson MM. Survivors of childhood and adolescent cancer: life-long risks and responsibilities. Nat Rev Cancer. 2014;14(1):61-70.

3. Zeltzer LK, Lu Q, Leisenring W, Tsao JC, Recklitis C, Armstrong G, Mertens AC, Robison LL, Ness KK. Psychosocial outcomes and health-related quality of life in adult childhood cancer survivors: a report from the childhood cancer survivor study. Cancer Epidemiol Biomarkers Prev. 2008;17(2):435-446. 
4. Pate RR, Pratt M, Blair SN, Haskell WL, Macera CA, Bouchard C, Buchner D, Ettinger W, Heath GW, King AC, et al. Physical activity and public health. A recommendation from the Centers for Disease Control and Prevention and the American College of Sports Medicine. JAMA. 1995;273(5):402-407.

5. Ness KK, Leisenring WM, Huang S, Hudson MM, Gurney JG, Whelan K, Hobbie WL, Armstrong GT, Robison LL, Oeffinger KC. Predictors of inactive lifestyle among adult survivors of childhood cancer: a report from the Childhood Cancer Survivor Study. Cancer. 2009;115(9):1984-1994.

6. Rueegg CS, Gianinazzi ME, Rischewski J, Beck Popovic M, von der Weid NX, Michel G, Kuehni CE. Health-related quality of life in survivors of childhood cancer: the role of chronic health problems. J Cancer Surviv. 2013;7(4):511-522.

7. Kadan-Lottick NS, Dinu I, Wasilewski-Masker K, Kaste S, Meacham LR, Mahajan A, Stovall M, Yasui Y, Robison LL, Sklar CA. Osteonecrosis in adult survivors of childhood cancer: a report from the childhood cancer survivor study. J Clin Oncol. 2008;26(18):3038-3045. 8. Ness KK, Baker KS, Dengel DR, Youngren N, Sibley S, Mertens AC, Gurney JG. Body composition, muscle strength deficits and mobility limitations in adult survivors of childhood acute lymphoblastic leukemia. Pediatr Blood Cancer. 2007;49(7):975-981.

9. Ness KK, Hudson MM, Ginsberg JP, Nagarajan R, Kaste SC, Marina N, Whitton J, Robison LL, Gurney JG. Physical performance limitations in the Childhood Cancer Survivor Study cohort. J Clin Oncol. 2009;27(14):2382-2389.

10. Oeffinger KC, Mertens AC, Sklar CA, Kawashima T, Hudson MM, Meadows AT, Friedman DL, Marina N, Hobbie W, Kadan-Lottick NS, Schwartz CL, Leisenring W, Robison LL. Chronic health conditions in adult survivors of childhood cancer. $N$ Engl J Med. 2006;355(15):1572-1582.

11. Gibson TM, Mostoufi-Moab S, Stratton KL, Leisenring WM, Barnea D, Chow EJ, Donaldson SS, Howell RM, Hudson MM, Mahajan A, Nathan PC, Ness KK, Sklar CA, Tonorezos ES, Weldon CB, Wells EM, Yasui Y, Armstrong GT, Robison LL, Oeffinger KC. Temporal patterns in the risk of chronic health conditions in survivors of childhood cancer diagnosed 1970-99: a report from the Childhood Cancer Survivor Study cohort. Lancet Oncol. 2018.

12. Chow EJ, Friedman DL, Yasui Y, Whitton JA, Stovall M, Robison LL, Sklar CA. Decreased adult height in survivors of childhood acute lymphoblastic leukemia: a report from the Childhood Cancer Survivor Study. J Pediatr. 2007;150(4):370-375, 375 e371.

13. Chow EJ, Liu W, Srivastava K, Leisenring WM, Hayashi RJ, Sklar CA, Stovall M, Robison LL, Baker KS. Differential effects of radiotherapy on growth and endocrine function among acute leukemia survivors: A childhood cancer survivor study report. Pediatr Blood Cancer. 2013;60(1):110-115.

14. Dalton VK, Rue M, Silverman LB, Gelber RD, Asselin BL, Barr RD, Clavell LA, Hurwitz CA, Moghrabi A, Samson Y, Schorin M, Tarbell NJ, Sallan SE, Cohen LE. Height and weight in children treated for acute lymphoblastic leukemia: relationship to CNS treatment. $J$ Clin Oncol. 2003;21(15):2953-2960.

15. Darzy KH, Shalet SM. Hypopituitarism as a consequence of brain tumours and radiotherapy. Pituitary. 2005;8(3-4):203-211.

16. Gurney JG, Kadan-Lottick NS, Packer RJ, Neglia JP, Sklar CA, Punyko JA, Stovall M, Yasui Y, Nicholson HS, Wolden S, McNeil DE, Mertens AC, Robison LL. Endocrine and 
cardiovascular late effects among adult survivors of childhood brain tumors: Childhood Cancer Survivor Study. Cancer. 2003;97(3):663-673.

17. Loeffler JS, Tarbell NJ, Garber JR, Mauch P. The development of Graves' disease following radiation therapy in Hodgkin's disease. Int J Radiat Oncol Biol Phys. 1988;14(1):175178.

18. Meacham LR, Gurney JG, Mertens AC, Ness KK, Sklar CA, Robison LL, Oeffinger KC. Body mass index in long-term adult survivors of childhood cancer: a report of the Childhood Cancer Survivor Study. Cancer. 2005;103(8):1730-1739.

19. Sklar C, Whitton J, Mertens A, Stovall M, Green D, Marina N, Greffe B, Wolden S, Robison L. Abnormalities of the thyroid in survivors of Hodgkin's disease: data from the Childhood Cancer Survivor Study. J Clin Endocrinol Metab. 2000;85(9):3227-3232.

20. Sklar CA, Mertens AC, Mitby P, Whitton J, Stovall M, Kasper C, Mulder J, Green D, Nicholson HS, Yasui Y, Robison LL. Premature menopause in survivors of childhood cancer: a report from the childhood cancer survivor study. J Natl Cancer Inst. 2006;98(13):890-896. 21. Meacham LR, Sklar CA, Li S, Liu Q, Gimpel N, Yasui Y, Whitton JA, Stovall M, Robison LL, Oeffinger KC. Diabetes mellitus in long-term survivors of childhood cancer. Increased risk associated with radiation therapy: a report for the childhood cancer survivor study. Arch Intern Med. 2009;169(15):1381-1388.

22. Mostoufi-Moab S, Seidel K, Leisenring WM, Armstrong GT, Oeffinger KC, Stovall M, Meacham LR, Green DM, Weathers R, Ginsberg JP, Robison LL, Sklar CA. Endocrine Abnormalities in Aging Survivors of Childhood Cancer: A Report From the Childhood Cancer Survivor Study. J Clin Oncol. 2016;34(27):3240-3247.

23. Chemaitilly W, Li Z, Huang S, Ness KK, Clark KL, Green DM, Barnes N, Armstrong GT, Krasin MJ, Srivastava DK, Pui CH, Merchant TE, Kun LE, Gajjar A, Hudson MM, Robison LL, Sklar CA. Anterior hypopituitarism in adult survivors of childhood cancers treated with cranial radiotherapy: a report from the St Jude Lifetime Cohort study. J Clin Oncol. 2015;33(5):492-500.

24. Robison LL, Armstrong GT, Boice JD, Chow EJ, Davies SM, Donaldson SS, Green DM, Hammond S, Meadows AT, Mertens AC, Mulvihill JJ, Nathan PC, Neglia JP, Packer RJ, Rajaraman P, Sklar CA, Stovall M, Strong LC, Yasui Y, Zeltzer LK. The Childhood Cancer Survivor Study: a National Cancer Institute-supported resource for outcome and intervention research. J Clin Oncol. 2009;27(14):2308-2318.

25. Ware JE, Jr., Sherbourne CD. The MOS 36-item short-form health survey (SF-36). I. Conceptual framework and item selection. Med Care. 1992;30(6):473-483.

26. Center for Disease Control and Prevention (CDC). Behavioral Risk Factor Surveillance System Survey Questionnaire. http://www.cdc.gov/brfss/questionaires/pdf-ques/2003brfss.pdf. Accessed March 19, 2018.

27. Diller L, Chow EJ, Gurney JG, Hudson MM, Kadin-Lottick NS, Kawashima TI, Leisenring WM, Meacham LR, Mertens AC, Mulrooney DA, Oeffinger KC, Packer RJ, Robison LL, Sklar CA. Chronic disease in the Childhood Cancer Survivor Study cohort: a review of published findings. J Clin Oncol. 2009;27(14):2339-2355.

28. Recklitis CJ, Parsons SK, Shih MC, Mertens A, Robison LL, Zeltzer L. Factor structure of the brief symptom inventory--18 in adult survivors of childhood cancer: results from the childhood cancer survivor study. Psychological assessment. 2006;18(1):22-32. 
29. Krull KR, Gioia G, Ness KK, Ellenberg L, Recklitis C, Leisenring W, Huang S, Stovall M, Robison LL, Zeltzer L. Reliability and validity of the Childhood Cancer Survivor Study Neurocognitive Questionnaire. Cancer. 2008;113(8):2188-2197.

30. Krull KR, Annett RD, Pan Z, Ness KK, Nathan PC, Srivastava DK, Stovall M, Robison LL, Hudson MM. Neurocognitive functioning and health-related behaviours in adult survivors of childhood cancer: a report from the Childhood Cancer Survivor Study. Eur J Cancer. 2011;47(9):1380-1388.

31. Quinque EM, Villringer A, Kratzsch J, Karger S. Patient-reported outcomes in adequately treated hypothyroidism - insights from the German versions of ThyDQoL, ThySRQ and ThyTSQ. Health Qual Life Outcomes. 2013;11:68.

32. Bianchi GP, Zaccheroni V, Solaroli E, Vescini F, Cerutti R, Zoli M, Marchesini G. Health-related quality of life in patients with thyroid disorders. Qual Life Res. 2004;13(1):45-54. 33. Saravanan P, Chau WF, Roberts N, Vedhara K, Greenwood R, Dayan CM. Psychological well-being in patients on 'adequate' doses of 1-thyroxine: results of a large, controlled community-based questionnaire study. Clin Endocrinol (Oxf). 2002;57(5):577-585.

34. Samuels MH, Schuff KG, Carlson NE, Carello P, Janowsky JS. Health status, psychological symptoms, mood, and cognition in L-thyroxine-treated hypothyroid subjects. Thyroid. 2007;17(3):249-258.

35. Bhasin S, Cunningham GR, Hayes FJ, Matsumoto AM, Snyder PJ, Swerdloff RS, Montori VM, Task Force ES. Testosterone therapy in men with androgen deficiency syndromes: an Endocrine Society clinical practice guideline. J Clin Endocrinol Metab. 2010;95(6):25362559.

36. Kenney LB, Cohen LE, Shnorhavorian M, Metzger ML, Lockart B, Hijiya N, DuffeyLind E, Constine L, Green D, Meacham L. Male reproductive health after childhood, adolescent, and young adult cancers: a report from the Children's Oncology Group. J Clin Oncol. 2012;30(27):3408-3416.

37. Romerius P, Stahl O, Moell C, Relander T, Cavallin-Stahl E, Wiebe T, Giwercman YL, Giwercman A. Hypogonadism risk in men treated for childhood cancer. J Clin Endocrinol Metab. 2009;94(11):4180-4186.

38. Aisenberg J, Hsieh K, Kalaitzoglou G, Whittam E, Heller G, Schneider R, Sklar C. Bone mineral density in young adult survivors of childhood cancer. J Pediatr Hematol Oncol. 1998;20(3):241-245.

39. Wasilewski-Masker K, Kaste SC, Hudson MM, Esiashvili N, Mattano LA, Meacham LR. Bone mineral density deficits in survivors of childhood cancer: long-term follow-up guidelines and review of the literature. Pediatrics. 2008;121(3):e705-713.

40. Molitch ME, Clemmons DR, Malozowski S, Merriam GR, Shalet SM, Vance ML, Stephens PA. Evaluation and treatment of adult growth hormone deficiency: an Endocrine Society Clinical Practice Guideline. J Clin Endocrinol Metab. 2006;91(5):1621-1634. 41. Hudson MM, Ness KK, Gurney JG, Mulrooney DA, Chemaitilly W, Krull KR, Green DM, Armstrong GT, Nottage KA, Jones KE, Sklar CA, Srivastava DK, Robison LL. Clinical ascertainment of health outcomes among adults treated for childhood cancer. JAMA. 2013;309(22):2371-2381.

42. Landier W, Armenian SH, Lee J, Thomas O, Wong FL, Francisco L, Herrera C, Kasper $\mathrm{C}$, Wilson KD, Zomorodi M, Bhatia S. Yield of screening for long-term complications using the children's oncology group long-term follow-up guidelines. J Clin Oncol. 2012;30(35):44014408 . 
Table 1: Demographic and treatment characteristics of adult survivors of childhood cancer with and without endocrine and metabolic disorders.

\begin{tabular}{|c|c|c|c|c|}
\hline \multirow[b]{2}{*}{ Characteristics } & \multirow[b]{2}{*}{$\begin{array}{l}\text { Total survivors } \\
\quad(\mathbf{N}=\mathbf{7 , 2 8 7})\end{array}$} & \multicolumn{3}{|c|}{ Survivors with and without endocrine and metabolic disorders } \\
\hline & & $\begin{array}{l}\text { With endocrine } \\
\text { disorders, } \mathbf{n}(\%) \\
(\mathbf{N}=\mathbf{4 8 8 4}) * *\end{array}$ & $\begin{array}{l}\text { Without endocrine } \\
\text { disorders, } \mathbf{n}(\%) \\
(\mathbf{N}=\mathbf{2 2 7 6}) * *\end{array}$ & p value* \\
\hline Sex & & & & $<0.001$ \\
\hline Male & $3566(48.94 \%)$ & $2504(51.3 \%)$ & $1011(44.4 \%)$ & \\
\hline Female & $3721(51.06 \%)$ & $2380(48.7 \%)$ & $1265(55.6 \%)$ & \\
\hline Race & & & & $<0.001$ \\
\hline White, non-Hispanic & $6586(90.38 \%)$ & $4386(89.8 \%)$ & $2086(91.7 \%)$ & 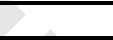 \\
\hline Black, non-Hispanic & $205(2.81 \%)$ & $134(2.7 \%)$ & $66(2.9 \%)$ & 2 \\
\hline Hispanic & $287(3.94 \%)$ & $226(4.6 \%)$ & $57(2.5 \%)$ & 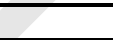 \\
\hline Other & $209(2.87 \%)$ & $138(2.8 \%)$ & $67(2.9 \%)$ & \\
\hline \multicolumn{5}{|l|}{ Age at diagnosis (years) } \\
\hline Mean \pm SD & $8(2-14)$ & $9(3-15)$ & $8(2-14)$ & $<0.001$ \\
\hline \multicolumn{5}{|l|}{ Age at survey (years) } \\
\hline Mean \pm SD & $32(24-40)$ & $33(25-40)$ & $31(23-38)$ & $<0.001$ \\
\hline \multicolumn{5}{|l|}{$\begin{array}{l}\text { Interval between cancer diagnosis and } \\
\text { assessment of endocrine function (years) }\end{array}$} \\
\hline Mean \pm SD & $24(19-28)$ & $24(19-28)$ & $23(19-28)$ & $<0.001$ \\
\hline Diagnosis & & & & $<0.001$ \\
\hline Leukemia & $2506(34.39 \%)$ & $1765(36.2 \%)$ & $684(30 \%)$ & \\
\hline CNS tumors & $896(12.30 \%)$ & $680(14 \%)$ & $203(8.9 \%)$ & \\
\hline Hodgkin lymphoma & $952(13.06 \%)$ & $764(15.6 \%)$ & $183(8.0 \%)$ & \\
\hline Non-Hodgkin lymphoma & $546(7.49 \%)$ & $369(7.6 \%)$ & $168(7.4 \%)$ & \\
\hline Wilms tumor & $664(9.11 \%)$ & $296(6.1 \%)$ & $354(15.6 \%)$ & \\
\hline Neuroblastoma & $469(6.44 \%)$ & $257(5.3 \%)$ & $199(8.7 \%)$ & \\
\hline Soft tissue sarcoma & $648(8.89 \%)$ & $419(8.6 \%)$ & $219(9.6 \%)$ & \\
\hline Ewing sarcoma & $191(2.62 \%)$ & $116(2.4 \%)$ & $75(3.3 \%)$ & \\
\hline Osteosarcoma & $390(5.35 \%)$ & $205(4.2 \%)$ & $180(7.9 \%)$ & \\
\hline Other & $25(0.34 \%)$ & $13(0.3 \%)$ & $11(0.5 \%)$ & \\
\hline Health insurance & 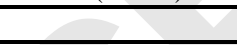 & & & 0.47 \\
\hline Yes & $6494(89.82 \%)$ & $4363(90.0 \%)$ & $2020(89.5 \%)$ & \\
\hline No & $736(10.18 \%)$ & $484(10.0 \%)$ & $238(10.5 \%)$ & \\
\hline Employed & 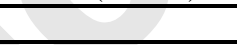 & & & $<0.001$ \\
\hline Yes & $6391(87.70 \%)$ & $4215(86.3 \%)$ & $2095(92.0 \%)$ & \\
\hline No & $896(12.30 \%)$ & $669(13.7 \%)$ & $181(8.0 \%)$ & \\
\hline Amputation & & & & $<0.001$ \\
\hline Yes & $384(5.27 \%)$ & $200(4.1 \%)$ & $175(7.7 \%)$ & \\
\hline No & $6903(94.73 \%)$ & $4684(95.9 \%)$ & $2101(92.3 \%)$ & \\
\hline Chemotherapy or radiation & & & & $<0.001$ \\
\hline No chemotherapy and no radiation & $526(7.68 \%)$ & $285(6.2 \%)$ & $231(10.9 \%)$ & \\
\hline With Chemotherapy or radiation & $6319(92.32 \%)$ & $4309(93.8 \%)$ & $1898(89.1 \%)$ & \\
\hline Any chemotherapy & & & & 0.004 \\
\hline Yes & $5362(79.19 \%)$ & $3549(78.2 \%)$ & $1711(81.2 \%)$ & \\
\hline No & $1409(20.81 \%)$ & $992(21.8 \%)$ & $395(18.8 \%)$ & \\
\hline Alkylating agents & & & & 0.03 \\
\hline Yes & $3356(49.56 \%)$ & $2294(50.5 \%)$ & $1004(47.7 \%)$ & \\
\hline No & $3415(50.44 \%)$ & $2247(49.5 \%)$ & $1102(52.3 \%)$ & \\
\hline $\begin{array}{l}\text { Alkylating cumulative equivalent dose } \\
(\mathrm{mg} / \mathrm{m} 2)\end{array}$ & & & & 0.005 \\
\hline mean \pm SD & 9974(1782-18167) & $10303(2066-18540)$ & $9375(1214-17536)$ & \\
\hline Steroids & & & & $<0.001$ \\
\hline Yes & $3286(48.53 \%)$ & $2320(51.1 \%)$ & $901(42.8 \%)$ & \\
\hline No & $3485(51.47 \%)$ & $2221(48.9 \%)$ & $1205(57.2 \%)$ & \\
\hline Stem-cell transplant & & & & 0.001 \\
\hline Yes & $295(4.06 \%)$ & $233(4.8 \%)$ & $59(2.6 \%)$ & \\
\hline No & $6976(95.94 \%)$ & $4639(95.2 \%)$ & $2213(97.4 \%)$ & \\
\hline Any radiation therapy ${ }^{* * * *}$ & & & & $<0.001$ \\
\hline Yes & $4480(65.68 \%)$ & $3318(72.5 \%)$ & $1089(51.3 \%)$ & \\
\hline No & $2341(34.32 \%)$ & $1256(27.5 \%)$ & $1035(48.7 \%)$ & \\
\hline
\end{tabular}




\begin{tabular}{|c|c|c|c|c|}
\hline Brain radiation therapy & & & & $<0.001$ \\
\hline Yes & $2301(34.37 \%)$ & $1834(40.9 \%)$ & $417(20.2 \%)$ & \\
\hline No & $4394(65.63 \%)$ & $2654(59.1 \%)$ & $1668(80.0 \%)$ & \\
\hline Brain RT dose (cGy) & & & & $<0.001$ \\
\hline mean \pm SD & $3003(1527-4480)$ & $3063(1569-4557)$ & $2772(1380-4165)$ & \\
\hline Chest radiation therapy & & & & $<0.001$ \\
\hline Yes & $1743(26.05 \%)$ & $1358(30.3 \%)$ & $374(17.9 \%)$ & \\
\hline No & $4947(73.95 \%)$ & $3125(69.7 \%)$ & $1711(82.1 \%)$ & \\
\hline Chest RT dose(cGy) & & & & $<0.001$ \\
\hline mean \pm SD & $2945(1742-4148)$ & $3032(1852-4212)$ & 2643(1407-3879) & \\
\hline Abdominal or pelvic radiation therapy & & & & $<0.001$ \\
\hline Yes & $1803(26.95 \%)$ & $1327(29.6 \%)$ & $452(21.7 \%)$ & - \\
\hline No & $4888(73.05 \%)$ & $3157(70.4 \%)$ & $1633(78.3 \%)$ & 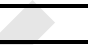 \\
\hline $\begin{array}{l}\text { The maximum RT dose to Abdominal and } \\
\text { pelvic(cGy) }\end{array}$ & & & & $<0.001$ \\
\hline mean \pm SD & $2810(1616-4004)$ & $2905(1712-4099)$ & $2564(1429-3700)$ & \\
\hline Total body irradiation (TBI) & & & 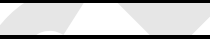 & $<0.001$ \\
\hline Yes & $92(1.38 \%)$ & $79(1.8 \%)$ & $12(0.6 \%)$ & \\
\hline No & $6596(98.62 \%)$ & $4402(98.2 \%)$ & $2073(99.4 \%)$ & \\
\hline $\begin{array}{l}\text { Grade 3-4 chronic health condition (other } \\
\text { than endocrine) }\end{array}$ & & & & $<0.001$ \\
\hline Yes & $5433(74.56 \%)$ & $3808(78.0 \%)$ & $1536(67.5 \%)$ & \\
\hline No & $1854(25.44 \%)$ & $1076(22.0 \%)$ & $740(32.5 \%)$ & \\
\hline Brief Symptom Inventory (BSI-18) & & & & 0.02 \\
\hline Yes & $600(9.57 \%)$ & $42610.2 \%)$ & $163(8.3 \%)$ & \\
\hline No & $5668(90.43 \%)$ & $3771(89.8 \%)$ & $1804(91.7 \%)$ & \\
\hline \multicolumn{5}{|l|}{ Neuro-cognitive status (NCQ) } \\
\hline Mean \pm SD & $54(40-67)$ & $54(41-68)$ & $52(40-64)$ & $<0.001$ \\
\hline
\end{tabular}

*Unknown value is not considered when calculating the p value except for household income.

**There are 127 survivors with missing value of endocrine disorders.

*** Childhood cancer survivors could belong to more than one radiation therapy category.

Table 2: Proportion of adult survivors of childhood cancers with specific endocrine and metabolic disorders.

\begin{tabular}{|c|c|c|}
\hline Endocrine disorder & CTCAE Grade (version 4.03) & Number $(\%)$ \\
\hline \multirow[t]{2}{*}{ Hyperthyroidism } & 1 & $66(0.91 \%)$ \\
\hline & 2 & $139(1.91 \%)$ \\
\hline \multirow[t]{2}{*}{ Hypothyroidism } & 1 & $138(1.89 \%)$ \\
\hline & 2 & $792(10.87 \%)$ \\
\hline \multirow[t]{2}{*}{ Thyroid nodules } & 2 & $140(1.92 \%)$ \\
\hline & $3^{*}$ & $329(4.51 \%)$ \\
\hline Thyroid cancer & Non-gradable & $67(0.9 \%)$ \\
\hline Short Stature & Non-gradable & $821(11.3 \%)$ \\
\hline \multirow[t]{2}{*}{ Growth hormone deficiency } & 1 & $211(2.90 \%)$ \\
\hline & 2 & $353(4.84 \%)$ \\
\hline \multirow[t]{3}{*}{ Gonadal dysfunction (males): testicular failure } & 1 & $29(0.81 \%)$ \\
\hline & 2 & $1(0.03 \%)$ \\
\hline & 3 & $53(1.49 \%)$ \\
\hline \multirow[t]{2}{*}{ Gonadal dysfunction (females): ovarian failure } & 1 & $4(0.11 \%)$ \\
\hline & 3 & $247(6.64 \%)$ \\
\hline Osteoporosis or osteopenia (low bone mineral density) & 2 & $376(5.16 \%)$ \\
\hline \multirow[t]{4}{*}{ Diabetes mellitus } & 1 & $51(0.70 \%)$ \\
\hline & 2 & $63(0.86 \%)$ \\
\hline & 3 & $60(0.82 \%)$ \\
\hline & 4 & $1(0.01 \%)$ \\
\hline Overweight/obesity & Non-gradable & $3699(50.7 \%)$ \\
\hline \multirow[t]{2}{*}{ Other endocrine disorders } & 1 & $112(1.54 \%)$ \\
\hline & 3 & $19(0.26 \%)$ \\
\hline
\end{tabular}

* Grade 3 thyroid nodules are those that resulted in surgery leading to a sub-total or total thyroidectomy. 
Table 3: Health related quality of life by type of endocrine/metabolic disorder among adult survivors of childhood cancers.

\begin{tabular}{|c|c|c|c|c|c|c|c|c|c|}
\hline \multirow{3}{*}{$\begin{array}{l}\text { SF-36 scale or } \\
\text { component } \\
\text { summary score }\end{array}$} & \multicolumn{9}{|c|}{ Endocrine disorder (Reference group = survivors with no endocrine disorder) } \\
\hline & $\begin{array}{c}\text { Any } \\
\text { thyroid } \\
\text { disorde } \\
\text { r }\end{array}$ & $\begin{array}{l}\text { Any } \\
\text { growth } \\
\text { disorde } \\
\text { rs }\end{array}$ & $\begin{array}{c}\text { Gonadal } \\
\text { dysfunction } \\
\text { (males) testicular } \\
\text { failure }\end{array}$ & $\begin{array}{c}\text { Gonadal } \\
\text { dysfunction } \\
\text { (females) ovarian } \\
\text { failure }\end{array}$ & $\begin{array}{l}\text { Osteo } \\
\text { poros } \\
\text { is }\end{array}$ & $\begin{array}{l}\text { Diab } \\
\text { etes }\end{array}$ & $\begin{array}{c}\text { Overw } \\
\text { eight/O } \\
\text { besity }\end{array}$ & $\begin{array}{c}\text { Other } \\
\text { endocrine } \\
\text { disorders not } \\
\text { specified }\end{array}$ & $\begin{array}{c}\text { An } \\
\text { y } \\
\text { end } \\
\text { ocr } \\
\text { ine } \\
\text { dis } \\
\text { ord } \\
\text { er }\end{array}$ \\
\hline & $\begin{array}{l}\text { RR* } \\
(\mathbf{9 5 \%} \\
\text { CI) }\end{array}$ & $\begin{array}{l}\mathbf{R R} \\
(\mathbf{9 5 \%} \\
\mathbf{C I})\end{array}$ & RR $(95 \%$ CI $)$ & $\mathbf{R R}(95 \% \mathbf{C I})$ & $\begin{array}{l}\mathbf{R R} \\
(\mathbf{9 5 \%} \\
\mathbf{C I})\end{array}$ & $\begin{array}{l}\mathbf{R R} \\
(\mathbf{9 5 \%} \\
\mathbf{C I})\end{array}$ & $\begin{array}{c}\mathbf{R R} \\
(\mathbf{9 5 \%} \\
\mathbf{C I})\end{array}$ & RR (95\% CI) & $\begin{array}{c}\text { RR } \\
(95 \\
\% \\
\text { CI }) \\
\end{array}$ \\
\hline $\begin{array}{l}\text { Physical } \\
\text { function }\end{array}$ & $\begin{array}{c}1.03 \\
(0.92- \\
1.15)\end{array}$ & $\begin{array}{l}1.14 \\
(0.99- \\
1.32)\end{array}$ & $1.52(1.10-2.10)$ & $1.44(1.18-1.76)$ & $\begin{array}{l}1.29 \\
(1.12- \\
1.50)\end{array}$ & $\begin{array}{r}1.37 \\
(1.04- \\
1.79)\end{array}$ & $\begin{array}{c}1.20 \\
(1.04- \\
1.38)\end{array}$ & $1.57(1.19-2.06)$ & $\begin{array}{l}1.2 \\
5 \\
(1.0 \\
5- \\
1.4 \\
8)\end{array}$ \\
\hline Role physical & $\begin{array}{l}1.25 \\
(1.10- \\
1.43)\end{array}$ & $\begin{array}{c}0.96 \\
(0.82- \\
1.14)\end{array}$ & $1.13(0.67-1.92)$ & $1.06(0.84-1.36)$ & $\begin{array}{l}1.41 \\
(1.20- \\
1.65)\end{array}$ & $\begin{array}{c}1.28 \\
(1.09- \\
1.50)\end{array}$ & $\begin{array}{l}1.00 \\
(0.89- \\
1.13)\end{array}$ & $1.37(1.00-1.87)$ & $\begin{array}{c}1.0 \\
9 \\
(0.9 \\
5- \\
1.2 \\
7)\end{array}$ \\
\hline Bodily pain & $\begin{array}{l}1.00 \\
(0.88- \\
1.14)\end{array}$ & $\begin{array}{c}0.79 \\
(0.68- \\
0.93)\end{array}$ & $1.58(1.20-2.09)$ & $1.31(1.06-1.62)$ & $\begin{array}{l}1.37 \\
(1.18- \\
1.61)\end{array}$ & $\begin{array}{c}1.36 \\
(1.09- \\
1.70)\end{array}$ & $\begin{array}{l}1.28 \\
(1.15- \\
1.42)\end{array}$ & $0.99(0.71-1.38)$ & $\begin{array}{c}1.2 \\
7 \\
(1.1 \\
2- \\
1.4 \\
4)\end{array}$ \\
\hline General health & $\begin{array}{l}1.27 \\
(1.15- \\
1.40)\end{array}$ & $\begin{array}{c}0.98 \\
(0.87- \\
1.11)\end{array}$ & $1.17(0.80-1.71)$ & $1.50(1.32-1.70)$ & $\begin{array}{l}1.45 \\
(1.30- \\
1.61)\end{array}$ & $\begin{array}{c}1.50 \\
(1.30- \\
1.72)\end{array}$ & $\begin{array}{l}1.26 \\
(1.15- \\
1.39)\end{array}$ & $1.14(0.91-1.43)$ & $\begin{array}{c}1.4 \\
9 \\
(1.3 \\
2- \\
1.6 \\
8)\end{array}$ \\
\hline Vitality & $\begin{array}{l}1.21 \\
(1.09- \\
1.35)\end{array}$ & $\begin{array}{c}0.95 \\
(0.83- \\
1.08)\end{array}$ & $1.59(1.13-2.25)$ & $1.13(0.94-1.36)$ & $\begin{array}{l}1.20 \\
(1.04- \\
1.39)\end{array}$ & $\begin{array}{c}1.46 \\
(1.28- \\
1.68)\end{array}$ & $\begin{array}{l}1.19 \\
(1.08- \\
1.30)\end{array}$ & $1.40(1.15-1.71)$ & $\begin{array}{c}1.2 \\
1 \\
(1.0 \\
9- \\
1.3 \\
4)\end{array}$ \\
\hline Role emotional & $\begin{array}{c}1.21 \\
(1.06- \\
1.38)\end{array}$ & $\begin{array}{c}0.89 \\
(0.77- \\
1.04)\end{array}$ & $1.57(1.07-2.30)$ & $1.06(0.83-1.34)$ & $\begin{array}{l}1.25 \\
(1.04- \\
1.49)\end{array}$ & $\begin{array}{c}0.93 \\
(0.66- \\
1.32)\end{array}$ & $\begin{array}{l}1.03 \\
(0.92- \\
1.15)\end{array}$ & $1.04(0.75-1.44)$ & $\begin{array}{c}1.0 \\
3 \\
(0.9 \\
1- \\
1.1 \\
7)\end{array}$ \\
\hline Social function & $\begin{array}{c}1.13 \\
(0.97- \\
1.32)\end{array}$ & $\begin{array}{c}0.84 \\
(0.70- \\
0.99)\end{array}$ & $1.63(1.21-2.20)$ & $1.48(1.17-1.87)$ & $\begin{array}{c}1.19 \\
(0.96- \\
1.47)\end{array}$ & $\begin{array}{l}1.47 \\
(1.12- \\
1.92)\end{array}$ & $\begin{array}{l}1.03 \\
(0.90- \\
1.17)\end{array}$ & $1.07(0.75-1.52)$ & $\begin{array}{c}1.0 \\
7 \\
(0.9 \\
2- \\
1.2 \\
4)\end{array}$ \\
\hline Mental health & $\begin{array}{c}1.04 \\
(0.90- \\
1.19)\end{array}$ & $\begin{array}{c}0.87 \\
(0.75- \\
1.02)\end{array}$ & 1.44 (1.08-1.91) & $1.24(0.99-1.56)$ & $\begin{array}{l}1.28 \\
(1.06- \\
1.54)\end{array}$ & $\begin{array}{c}1.19 \\
(0.88- \\
1.60)\end{array}$ & $\begin{array}{l}1.05 \\
(0.94- \\
1.17)\end{array}$ & $1.09(0.80-1.47)$ & $\begin{array}{c}1.0 \\
9 \\
(0.9 \\
6- \\
1.2 \\
4) \\
\end{array}$ \\
\hline $\begin{array}{c}\text { Physical } \\
\text { component } \\
\text { summary }\end{array}$ & $\begin{array}{l}1.09 \\
(0.95- \\
1.24)\end{array}$ & $\begin{array}{c}0.99 \\
(0.83- \\
1.18) \\
\end{array}$ & $1.01(0.55-1.85)$ & $1.26(1.08-1.46)$ & $\begin{array}{c}1.45 \\
(1.29- \\
1.63)\end{array}$ & $\begin{array}{c}1.23 \\
(1.08- \\
1.40)\end{array}$ & $\begin{array}{l}1.25 \\
(1.12- \\
1.38)\end{array}$ & $1.51(1.15-1.99)$ & $\begin{array}{l}1.3 \\
0\end{array}$ \\
\hline
\end{tabular}




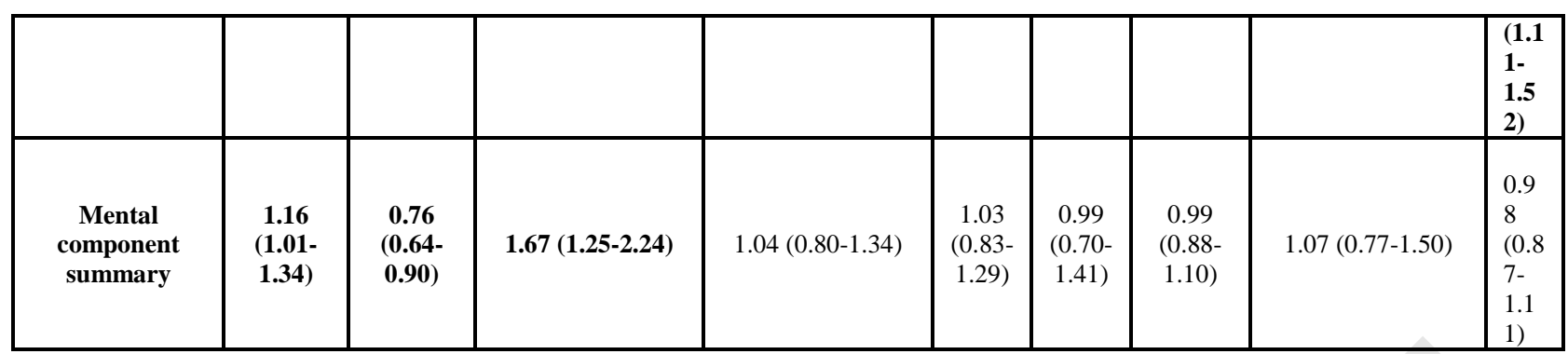

Adjusted for sex, race, education, marital status, household income, health insurance, employment status, radiation yes/no, amputation, and other grade 3-4 chronic conditions.

*Risk ratio.

Table 4: Effect of number of endocrine and metabolic disorders on SF-36 subscales among adult survivors of childhood cancers.

\begin{tabular}{|c|c|c|c|c|c|c|}
\hline \multirow{3}{*}{$\begin{array}{l}\text { SF-36 scale or } \\
\text { component } \\
\text { summary } \\
\text { score }\end{array}$} & \multicolumn{6}{|c|}{ Number of endocrine and metabolic disorders* } \\
\hline & 1 vs. none & 2 vs. none & $>2$ vs. none & 2 vs. 1 & $>2$ vs 1 & $>2$ vs 2 \\
\hline & $\mathbf{R R} *(95 \% \mathbf{C I})$ & RR $(95 \%$ CI) & RR (95\%CI) & RR (95\% CI) & RR (95\% CI) & RR (95\% CI) \\
\hline $\begin{array}{l}\text { Physical } \\
\text { function }\end{array}$ & $1.2(0.9-1.6)$ & $1.6(1.1-2.2)$ & $1.8(1.2-2.7)$ & $1.3(0.96-1.8)$ & $1.4(0.99-2.1)$ & $1.1(0.7-1.7)$ \\
\hline Role Physical & $1.0(0.8-1.2)$ & $1.3(1.1-1.6)$ & $1.3(0.99-1.6)$ & $1.3(1.1-1.6)$ & $1.3(1.03-1.6)$ & $1.0(0.8-1.2)$ \\
\hline Bodily pain & $1.2(1.1-1.4)$ & $1.3(1.1-1.5)$ & $1.4(1.2-1.8)$ & $1.0(0.9-1.2)$ & $1.2(0.9-1.4)$ & $1.1(0.9-1.4)$ \\
\hline $\begin{array}{c}\begin{array}{c}\text { General } \\
\text { health }\end{array} \\
\end{array}$ & $1.3(1.2-1.5)$ & $1.7(1.5-2.0)$ & $2.0(1.7-2.4)$ & $1.3(1.1-1.5)$ & $1.5(1.3-1.7)$ & $1.1(0.98-1.3)$ \\
\hline Vitality & $1.1(0.99-1.3)$ & $1.4(1.2-1.6)$ & $1.6(1.3-1.9)$ & $1.2(1.1-1.4)$ & $1.4(1.2-1.7)$ & $1.2(0.97-1.4)$ \\
\hline $\begin{array}{c}\text { Role } \\
\text { emotional }\end{array}$ & $1.0(0.9-1.1)$ & $1.1(0.97-1.3)$ & $1.2(0.9-1.4)$ & $1.2(1.01-1.3)$ & $1.2(0.98-1.5)$ & $1.0(0.8-1.3)$ \\
\hline $\begin{array}{c}\text { Social } \\
\text { function }\end{array}$ & $1.0(0.9-1.2)$ & $1.1(0.9-1.3)$ & $1.3(1.04-1.6)$ & $1.0(0.9-1.2)$ & $1.3(1.03-1.6)$ & $1.2(0.97-1.5)$ \\
\hline Mental health & $1.1(0.9-1.2)$ & $1.1(0.9-1.3)$ & $1.3(1.02-1.5)$ & $1.0(0.8-1.1)$ & $1.2(0.96-1.4)$ & $1.2(0.97-1.5)$ \\
\hline $\begin{array}{l}\text { Physical } \\
\text { component } \\
\text { summary }\end{array}$ & $1.2(0.9-1.5)$ & $1.6(1.3-2.1)$ & $1.7(1.3-2.4)$ & $1.4(1.1-1.8)$ & $1.5(1.1-2.0)$ & $1.1(0.8-1.4)$ \\
\hline $\begin{array}{c}\text { Mental } \\
\text { component } \\
\text { summary }\end{array}$ & $1.0(0.8-1.1)$ & $1.0(0.9-1.2)$ & $1.0(0.8-1.3)$ & $1.1(0.9-1.3)$ & $1.0(0.8-1.3)$ & $1.0(0.8-1.2)$ \\
\hline
\end{tabular}

*Adjusted for sex, race, education, marital status, household income, health insurance, employment status, other grade 3-4 chronic condition, radiation yes/no, amputation, and task efficiency. The adjusted number of outcomes and percentages were calculated based on the survivors with endocrine information.

**Risk ratio

Table 5: Physical activity among adult survivors of childhood cancer and type of endocrine/metabolic disorder.

\begin{tabular}{|c|c|c|c|}
\hline Endocrine or metabolic disorder & Value & $\begin{array}{c}\text { Recent participation in any organized } \\
\text { physical activities. } N(\%) *\end{array}$ & $\begin{array}{l}\text { Meets CDC guidelines for physical } \\
\text { activity. N }(\%) *\end{array}$ \\
\hline \multirow{3}{*}{ Thyroid disorders } & $\begin{array}{l}\text { Yes } \\
(\mathrm{N}=1247)\end{array}$ & $966(77.5 \%)$ & $653(52.4 \%)$ \\
\hline & No $(\mathrm{N}=6042)$ & $4738(78.4 \%)$ & $3382(56.0 \%)$ \\
\hline & $\begin{array}{l}\text { RR** of Yes } \\
\text { vs. No }\end{array}$ & $1.02(0.99-1.06)$ & $1.04(0.97-1.10)$ \\
\hline \multirow{3}{*}{ Growth Disorders } & $\begin{array}{l}\text { Yes } \\
(\mathrm{N}=1121)\end{array}$ & $798(71.2 \%)$ & $517(46.1 \%)$ \\
\hline & No $(\mathrm{N}=6118)$ & $4867(79.6 \%)$ & $3489(57.0 \%)$ \\
\hline & $\begin{array}{l}\text { RR of Yes vs. } \\
\text { No }\end{array}$ & $0.95(0.91-0.99)$ & $0.90(0.83-0.97)$ \\
\hline \multirow{3}{*}{$\begin{array}{c}\text { Gonadal dysfunction (Males): } \\
\text { testicular failure }\end{array}$} & Yes $(\mathrm{N}=83)$ & $59(72.0 \%)$ & $41(50.6 \%)$ \\
\hline & No $(\mathrm{N}=3485)$ & $2775(79.9 \%)$ & $2114(61.8 \%)$ \\
\hline & RR of Yes vs. & $0.93(0.81-1.06)$ & $0.96(0.77-1.19)$ \\
\hline
\end{tabular}




\begin{tabular}{|c|c|c|c|}
\hline & No & & \\
\hline \multirow{3}{*}{$\begin{array}{c}\text { Gonadal dysfunction (females): } \\
\text { ovarian failure }\end{array}$} & Yes $(\mathrm{N}=251)$ & $183(72.9 \%)$ & $106(43.1 \%)$ \\
\hline & No $(N=3470)$ & $2687(77.7 \%)$ & $1774(51.8 \%)$ \\
\hline & $\begin{array}{l}\text { RR of Yes vs. } \\
\text { No }\end{array}$ & $0.95(0.88-1.04)$ & $0.88(0.75-1.03)$ \\
\hline \multirow{3}{*}{ Osteoporosis } & Yes $(N=376)$ & $269(71.5 \%)$ & $164(43.6 \%)$ \\
\hline & No $(\mathrm{N}=6913)$ & $5435(78.6 \%)$ & $3871(56.0 \%)$ \\
\hline & $\begin{array}{l}\text { RR of Yes vs. } \\
\text { No }\end{array}$ & $0.94(0.87-1.01)$ & $0.87(0.76-0.99)$ \\
\hline \multirow{3}{*}{ Diabetes } & Yes $(\mathrm{N}=175)$ & $114(65.1 \%)$ & $72(41.1 \%)$ \\
\hline & No $(\mathrm{N}=7114)$ & $5590(78.6 \%)$ & $3963(55.7 \%)$ \\
\hline & $\begin{array}{l}\text { RR of Yes vs. } \\
\text { No }\end{array}$ & $0.84(0.74-0.96)$ & $0.82(0.67-1.0008)$ \\
\hline \multirow{3}{*}{ Overweight/Obesity } & $\begin{array}{l}\text { Yes } \\
(\mathrm{N}=3699)\end{array}$ & $2834(76.6 \%)$ & $1969(53.2 \%)$ \\
\hline & No $(\mathrm{N}=3389)$ & $2732(80.6 \%)$ & $1979(58.4 \%)$ \\
\hline & $\begin{array}{l}\text { RR of Yes vs. } \\
\text { No }\end{array}$ & $0.97(0.95-1.00)$ & $0.92(0.88-0.96)$ \\
\hline \multirow{3}{*}{ Other endocrine disorders } & Yes $(\mathrm{N}=131)$ & $100(76.3 \%)$ & $56(42.7 \%)$ \\
\hline & No $(\mathrm{N}=7158)$ & $5604(78.3 \%)$ & $3979(55.6 \%)$ \\
\hline & $\begin{array}{l}\text { RR of Yes vs. } \\
\text { No }\end{array}$ & $1.02(0.92-1.13)$ & $0.82(0.65-1.03)$ \\
\hline
\end{tabular}

* Adjusted for sex, race, education, marital status, household income, health insurance, employment status, other grade 3-4 chronic condition, emotional health (BSI 18), radiation yes/no, amputation, and task efficiency. The adjusted number of outcomes and percentages were calculated based on the survivors with endocrine information. **Risk ratio

Table 6: Effect of number of endocrine and metabolic disorders on physical activity among adult survivors of childhood cancer.

\begin{tabular}{|c|c|c|c|}
\hline \multirow{12}{*}{$\begin{array}{l}\text { Number of endocrine and } \\
\text { metabolic disorders }\end{array}$} & Value & $\begin{array}{c}\text { Recent participation in any organized } \\
\text { physical activities. } \mathbf{N}(\%) *\end{array}$ & $\begin{array}{l}\text { Meets CDC guidelines for } \\
\text { physical activity. } \mathrm{N}(\%) *\end{array}$ \\
\hline & $1(\mathrm{~N}=3257)$ & $2547(78.2 \%)$ & $1819(55.8 \%)$ \\
\hline & $2(\mathrm{~N}=1176)$ & $887(75.4 \%)$ & $587(49.9 \%)$ \\
\hline & $>2(\mathrm{~N}=451)$ & $309(68.5 \%)$ & $181(40.1 \%)$ \\
\hline & $\begin{array}{l}\text { No endocrine/metabolic } \\
\text { disorder }(\mathrm{N}=2278)\end{array}$ & $1868(82.0 \%)$ & $1385(60.9 \%)$ \\
\hline & 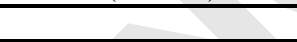 & \multicolumn{2}{|c|}{$\mathbf{R R}^{* *(95 \% \text { CI })}$} \\
\hline & $\begin{array}{l}1 \text { vs. No } \\
\text { endocrine/metabolic } \\
\text { disorder }\end{array}$ & $0.98(0.96-1.005)$ & $0.93(0.89-0.98)$ \\
\hline & $\begin{array}{l}2 \text { vs. No } \\
\text { endocrine/metabolic } \\
\text { disorder }\end{array}$ & $0.96(0.92-1.001)$ & $0.91(0.85-0.98)$ \\
\hline & $\begin{array}{l}2 \text { vs. No } \\
\text { endocrine/metabolic } \\
\text { disorder }\end{array}$ & $0.90(0.83-0.97)$ & $0.76(0.67-0.85)$ \\
\hline & 2 vs. 1 & $0.98(0.94-1.02)$ & $0.98(0.92-1.06)$ \\
\hline & $>2$ vs. 1 & $0.92(0.85-0.99)$ & $0.82(0.72-0.94)$ \\
\hline & $>2$ vs. 2 & $0.93(0.86-1.01)$ & $0.84(0.73-0.96)$ \\
\hline
\end{tabular}

*Adjusted for sex, race, education, marital status, household income, health insurance, employment status, other grade 3-4 chronic condition, emotional health (BSI 18), radiation yes/no, amputation, and task efficiency. The adjusted number of outcomes and percentages were calculated based on the survivors with endocrine information. **Risk ratio

Table 7: Adjusted risk-ratios of SF-36 outcomes between survivors with endocrine conditions reporting medication use for hormone replacement compared to those not on hormone replacement therapy.

\begin{tabular}{|c|l|l|l|}
\hline $\begin{array}{c}\text { SF-36 scale or } \\
\text { component } \\
\text { summary score }\end{array}$ & $\begin{array}{l}\text { Survivors with hypothyroidism on } \\
\text { replacement therapy at } 2003 \text { survey } \\
\text { compared to survivors with no }\end{array}$ & $\begin{array}{l}\text { Males with gonadal dysfunction on } \\
\text { testosterone therapy at 2003 survey } \\
\text { compared to survivors with no }\end{array}$ & $\begin{array}{l}\text { Females with gonadal } \\
\text { dysfunction on HRT at 2003 } \\
\text { survey compared to survivors }\end{array}$ \\
\hline
\end{tabular}




\begin{tabular}{|c|c|c|c|}
\hline & replacement $(\mathrm{N}=110) *$ & replacement $(\mathrm{N}=51) *$ & with no replacement $(\mathrm{N}=168)$ * \\
\hline Physical function & $1.00(0.96-1.04)$ & $0.19(0.04-0.88)$ & $0.90(0.53-1.55)$ \\
\hline Role Physical & $1.23(0.61-2.50)$ & $0.71(0.71-2.53)$ & $1.01(0.57-1.80)$ \\
\hline Bodily pain & $1.08(0.64-1.81)$ & $0.47(0.15-1.50)$ & $0.84(0.55-1.26)$ \\
\hline General health & $0.81(0.50-1.32)$ & $0.40(0.14-1.19)$ & $0.85(0.62-1.15)$ \\
\hline Vitality & $0.78(0.50-1.22)$ & $0.54(0.25-1.18)$ & $0.72(0.48-1.09)$ \\
\hline Role emotional & $0.74(0.48-1.13)$ & $0.38(0.15-0.98)$ & $1.02(0.58-1.82)$ \\
\hline Social function & $0.89(0.46-1.69)$ & $0.22(0.05-0.97)$ & $0.99(0.71-1.38)$ \\
\hline Mental health & $0.58(0.36-0.93)$ & $0.22(0.06-0.86)$ & $1.07(0.65-1.77)$ \\
\hline $\begin{array}{c}\text { Physical } \\
\text { component } \\
\text { summary }\end{array}$ & $0.77(0.45-1.32)$ & $0.16(0.02-1.56)$ & $1.09(0.62-1.91)$ \\
\hline $\begin{array}{c}\text { Mental } \\
\text { component } \\
\text { summary }\end{array}$ & $0.75(0.41-1.36)$ & $0.48(0.16-1.43)$ & $1.16(0.62-2.20)$ \\
\hline
\end{tabular}

*Adjusted for sex (only for testosterone therapy and HRT), race, education, marital status, household income, health insurance, employment status, radiation yes/no, amputation, and other grade 3-4 chronic condition.

HRT: hormone replacement therapy 